\title{
logopaedica
ogziensia
}

$\operatorname{Nr} 1$ (2017)

DOl: http://dx.doi.org/10.18778/2544-7238.01.16

\author{
Ewelina Zając*
}

\section{Sprawozdanie z konkursów logopedycznych}

Logopedzi, zwłaszcza pracujący w przedszkolach i szkołach, coraz częściej organizują konkursy logopedyczne w celu uatrakcyjnienia zajęć logopedycznych oraz zmobilizowania dzieci objętych terapią logopedyczną do codziennych ćwiczeń. Te przeprowadzane w przedszkolach najczęściej mają charakter logopedyczno-plastyczny, tzn. zadaniem dzieci jest namalowanie ilustracji zawierającej wyrazy z głoskami sprawiającymi im najwięcej trudności. Celem takich konkursów jest rozbudzenie językowej i plastycznej twórczości u dzieci, zwłaszcza tych z trudnościami w mówieniu, prezentacja ich umiejętności i zdolności plastycznych oraz wspólna praca logopedy, rodzica i dziecka nad rozwojem mowy z wykorzystaniem technik plastycznych.

W listopadzie bieżącego roku konkursy logopedyczne po raz pierwszy zorganizowane zostały w Zespole Szkół w Przykonie (powiat turecki, województwo wielkopolskie). Odbywały się one w trzech kategoriach wiekowych: dla dzieci przedszkolnych oraz dla uczniów klas I-III i IV-VII szkoły podstawowej.

"Grzybobranie z panem Szymonem” to konkurs logopedyczno-plastyczny adresowany do dzieci przedszkolnych w wieku od 3 do 6 lat. Zadaniem przedszkolaków było samodzielne namalowanie ilustracji związanej z tematyką grzybobrania, jednak ilustracja musiała zawierać jak najwięcej elementów z głoskami szeregu szumiącego [sz, $\dot{z} / \mathrm{rz}, \mathrm{cz}, \mathrm{d} \dot{z}]$. Konkurs skierowany był nie tylko do dzieci objętych terapią logopedyczną, ale do wszystkich zainteresowanych. Nagrodzonych zostało dwanaście prac: dwie $\mathrm{w}$ grupie dzieci czteroletnich oraz po pięć w grupach dzieci pięcio- i sześcioletnich.

Do uczniów klas I-III szkoły podstawowej skierowany było konkurs logopedyczno-plastyczny „W Szczebrzeszynie chrząszcz brzmi w trzcinie... i inne łamańce językowe". Zadaniem uczestników było samodzielne namalowanie ilustracji do jednego z polskich łamańców językowych, np. chrzaszcz brzmi w trzcinie, król Karol kupit królowej Karolinie korale koloru koralowego i innych. Konkurs cieszył się dużym za-

\footnotetext{
* Zakład Dialektologii Polskiej i Logopedii, Instytut Filologii Polskiej i Logopedii, Wydział Filologiczny Uniwersytetu Łódzkiego, ul. Pomorska 171/173, 90-236 Łódź, ewelina.zajac@uni.lodz.pl.
} 
interesowaniem. Spośród wszystkich zgłoszonych prac nagrodzono trzy najlepsze oraz przyznano osiem wyróżnień.

Trzeci konkurs - „Wierszyki wyginające języki” - skierowany był do uczniów klas IV-VII szkoły podstawowej. Zadanie było bardzo wymagające, ponieważ należało samodzielnie napisać wiersz z jak największą liczbą wyrazów z głoskami szumiącymi i głoską [r]. Spośród zgłoszonych utworów nagrodzono trzy wiersze oraz wyróżniono dwa (poniżej).

Głównym sponsorem nagród w konkursach był Zakład Dialektologii Polskiej i Logopedii Uniwersytetu Łódzkiego, wydawnictwo MOJE BAMBINO oraz Księgarnia i Hurtownia Taniej Książki w Żychlinie.

\section{I miejsce}

Dominik Pokojewski (klasa VIIa)

„Dżess”

Czy Ty wiesz, jakie imię ma ten jeż???

Ten jeż to jest Dżess - mój ukochany zwierz.

Schował się pod wielki kierz, kiedy padał duży deszcz.

Pozjadał porzeczki, które rosły koło rzeczki.

Wszedł też do mojej teczki i poszarpał mi karteczki.

Płaczę, krzyczę:

- Jejku, Dżess! Przecież to mój sprawdzian jest!

- Coś ty zrobił, mój jeżyku? - narobiłem dużo krzyku.

Próżne było me błaganie, bo jeż nadal miał swe zdanie:

- Mój kochany Dominiku, byłem też w twoim piórniku!

Poszperałem tam, gdzie chciałem, a na książkach się przespałem - roześmiał się jeż.

\section{II miejsce}

Karolina Zielińska (klasa VIa)

„Podróż”

Narzekająca Marzenka nad morze się wybrała, całą podróż narzekała:

a to, że droga jej się dłuży,

a to, że pasażer oczy mruży,

a to, że książka ją nuży,

a to, że podróżni grzebią w bagażach,

a to, że pasażerka pożera głośno pożywienie,

a to, że duże kałuże i wyżłobione kamienie. 
Narzekała, narzekała, aż nad morze dojechała, na plaży się położyła i się rozmarzyła. Marzyła, marzyła, a gdy się obudziła, to zauważyła, że się zesmażyła.

\section{III miejsce}

Sebastian Rykała (klasa IVa)

„Nieszczęście Żuczka Szalki”

Żuczek Szalka idzie szosą, niesie śliwkę fioletową.

Idzie sobie dziarskim krokiem, idzie ścieżką wrzosową.

Idzie borem w odwiedziny do jeżyka, do jeżyka Koralika.

Nagle staje, widzi grzyba, czeka cicho, a ten znika.

I tak jeżyk czmycha sobie. Szuka szczęścia.

Dookoła się rozgląda. Coś szeleści, nie ma przejścia.

Wtem usłyszał Żuczka głosik:

- Drogi jeżu. Gdzie ty chodzisz, dokąd zmierzasz?

Przecież gościem jestem twoim!

Ty ugościć mnie królewsko nie zamierzasz?

Gdzie jedzenie? Gdzie te stoły w progu twoim?

- Żuczku mały, nie rozumiesz? Tyś kolacją moją.

Na talerzu wylądujesz! Uraduję duszę swoją.

Żuczek szarpie się, wyrywa jak w wodzie płocie.

Nagle jeżyk HAPS! Połyka żuka w locie.

Z tej przyjaźni nie wynikło nic dobrego:

Zastanów się więc dobrze, nim pójdziesz do nieznajomego.

\section{Wyróżnienie}

Natalia Korzepa (klasa VIa)

„Rzepa”

Rzekła rzepa rzepakowi:

- Wciąż mnie brzuszek bardzo boli.

Usłyszała to gżegżółka - dobra rzepy przyjaciółka, więc mówi tak:

- Przełknij trzy rzodkiewki, jarzyny, grzybków parę,

popij oranżadą

i poczekaj, aż brzuszek boleć przestanie.

Inną poradę miała żaba Żaneta:

- Idź do lekarza i nie narzekaj. 
Natomiast jeż Błażejek tak oto powiada:

- Zjedz garść żołędzi, to mi pomaga.

Lecz rzepa Bożena nikogo nie posłuchała

i jeszcze bardziej się rozchorowała.

Musiała położyć się do łóżka.

Aż po chwili nad grzejnikiem pojawiła się różowa wróżka.

Wyciągnęła swą różdżkę i rzekła:

- Sprawię, że brzuch cię przestanie boleć,

ale przyrzeknij, że będziesz rad koleżanek i kolegów słuchała

i uwag moich przestrzegała.

Cóż miała robić biedna rzepka, zasady tej przyrzekła.

I już zawsze była grzeczna.

Gdyż tak wypada, aby słuchać też innych, a nie tylko samemu sobie doradzać.

\section{Wyróżnienie}

Jakub Skopiński (klasa VIb)

„Srebrzysty czas”

Bywa, że jesień szarą ma twarz.

Bywa, że deszczem zmoczy też nas.

Lecz ja uwielbiam ten kolorowy czas,

A do mojej opowieści, zaproszę też Was.

Gruszki, jarzębina, kasztany,

Cały jesienny świat jest zwariowany.

Z szelestem żółte liście lecą,

Wkrótce cały ogród rozświecą.

$\mathrm{Z}$ dębu spadają żołędzie,

Wesoły ludzik z nich będzie.

Nad głowami przelatuje sznur żurawi,

Gęś gęgawa, gołąb grzywacz i pokrzewka,

Też na jakiś czas kraj zostawi.

Na rozlewiskach zbierają się chmary czajek,

Wieczór szybko nadchodzi, to czas czytania bajek.

Rankiem mgła otula nas,

Prawda, że jesień to piękny czas? 